GRASAS Y ACEITES 67 (1)

January-March 2016, e115

ISSN-L: 0017-3495

doi: http://dx.doi.org/10.3989/gya.0496151

\title{
Conversion of Oleum papaveris seminis oil into methyl esters via esterification process: Optimization and kinetic study
}

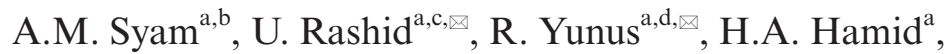 \\ S.I. Al-Resayes ${ }^{\mathrm{c}}$, I.A. Nehdi ${ }^{\mathrm{c}}$ and A.H. Al-Muhtaseb ${ }^{\mathrm{e}}$ \\ ${ }^{a}$ Institute of Advanced Technology, Universiti Putra Malaysia, 43400 UPM Serdang, Selangor, Malaysia \\ ${ }^{\mathrm{b}}$ Department of Chemical Engineering, University of Malikussaleh 24351, Lhokseumawe, Indonesia \\ ${ }^{c}$ Chemistry Department, College of Science, King Saud University, Riyadh 1145, Saudi Arabia \\ ${ }^{\mathrm{d}}$ Department of Chemical and Environmental Engineering, Faculty of Engineering, \\ Universiti Putra Malaysia, 43400 UPM Serdang, Selangor, Malaysia \\ ${ }^{e}$ Petroleum and Chemical Engineering Department, Faculty of Engineering, Sultan Qaboos University, Muscat 123, Oman \\ Corresponding authors: umer.rashid@yahoo.com; robiah@upm.edu.my
}

Submitted: 17 April 2015; Accepted: 20 August 2015

SUMMARY: This paper presents an acid pre-treatment process and a kinetic study for the esterification reaction of Oleum papaveris seminis oil with methanol in the presence of amberlite 120 as a solid catalyst to convert the oil into methyl esters. Response surface methodology (RSM) was applied to optimize the reaction parameters, i.e. reaction time, percentage of the catalyst and volume ratio of methanol to oil. The results revealed that $0.87 \% \mathrm{w} / \mathrm{w}$ of catalyst concentration and $44.70 \% \mathrm{v} / \mathrm{v}$ of methanol to oil ratio provided final free fatty acid (FFA) contents of $0.60 \% \mathrm{w} / \mathrm{w}$ at $102.40 \mathrm{~min}$ of reaction time. It proved that the contribution of Amberlite 120 in the esterification of FFA was highly significant. The kinetics of the esterification in Oleum papaveris seminis oil with methanol in the presence of the amberlite 120 catalyst were also investigated to establish the reaction rate constant $(k)$, reaction order, and activation energy. The study was performed under the optimized parameters at three reaction temperatures $\left(50,55\right.$, and $\left.60{ }^{\circ} \mathrm{C}\right)$. The value of $k$ was in the range of 0.013 to $0.027 \mathrm{~min}^{-1}$. The first-order kinetics' model was suitable for this irreversible FFA esterification with the activation energy of about $60.9 \mathrm{KJ} \cdot \mathrm{mol}^{-1}$.

KEYWORDS: Amberlite 120; Esterification; Kinetics; Oleum Papaveris Seminis Oil; Response Surface Methodology

RESUMEN: Conversión de Oleum papaveris seminis en ésteres metilicos mediante un proceso de esterificación: Optimización y estudio cinético. En este artículo se presenta un proceso de pre-tratamiento con ácido, y un estudio cinético de la reacción de esterificación. Se utiliza Oleum papaveris seminis con metanol en presencia de Amberlite 120 como catalizador sólido para la formación de los ésteres metílicos. Se aplicó una metodología de superficie de respuesta (RSM) para optimizar los parámetros de la reacción; es decir, tiempo de reacción, porcentaje de la relación de catalizador y volumen de metanol - aceite. Los resultados mostraron que el 0,87\% w/w de la concentración de catalizador y 44,70\% v/v de metanol en relación al aceite dan lugar a un contenido final de ácidos grasos libres (FFA) de 0,60\% w/w en 102,40 min de tiempo de reacción. Se demostró que la contribución de Amberlite 120 en la esterificación de los FFA fue altamente significativa. La cinética de la esterificación del Oleum papaveris Seminis con metanol en presencia del catalizador Amberlite 120 también se investigó para establecer la constante de velocidad de reacción $(\mathrm{k})$, orden de la reacción, y la energía de activación. El estudio se realizó bajo los parámetros optimizados a tres temperaturas de reacción $\left(50,55\right.$, y $\left.60^{\circ} \mathrm{C}\right)$. El valor de la constante $\mathrm{k}$ fué del rango de 0.013 a $0,027 \mathrm{~min}^{-1}$. El modelo de cinética de primer orden fue el adecuado para esta esterificación FFA irreversible con una energía de activación de aproximadamente $60,9 \mathrm{KJ} \mathrm{mol}^{-1}$. 
Citation/Cómo citar este artículo: Syam AM, Rashid U, Yunus R, Hamid HA, Al-Resayes SI, Nehdi IA, Al-Muhtaseb AH. 2016. Conversion of Oleum papaveris seminis oil into methyl esters via esterification process: Optimization and kinetic study. Grasas Aceites 67 (1): e115. doi: http://dx.doi.org/10.3989/gya.0496151.

Copyright: (C) 2016 CSIC. This is an open-access article distributed under the terms of the Creative Commons Attribution-Non Commercial (by-nc) Spain 3.0 Licence.

\section{INTRODUCTION}

The shortage of petroleum reserves and other environmental issues has encouraged governments and researchers to look for alternative sources of fuel. Vegetable oil, animal fat and waste oil have been investigated as the feedstock for biodiesel. Most research findings have proved that biodiesel is a good substitute for petroleum diesel in compression ignition engines since it fulfils the international standards for automotive use (Ma and Hanna, 1999). Unfortunately, the growth of the biofuel industry has faded due to economic crises, which have culminated in significant decreases in fossil fuel prices (Mohr et al., 2015). Moreover, it has been the reverse for prices of food crops especially soy and corn, which are the major contributors to biodiesel production. Their prices have increased (Radijiyev et al., 2015). Considering these facts, in order to deal with the uncertainty of biodiesel production, studies have been focused on finding non-edible oil sources for biodiesel production (Aransiola et al., 2014). In order to avoid a food versus fuel controversy, there is an ultimate need for exploration of non-edible resources and this will lead to minimizing the cost factor for biodiesel production (Wu et al., 2014). Despite this, there are several factors which are of major concern for the adaption of biodiesel technology related to the environment, such as a reduction in greenhouse gases and easily biodegradable waste. While for energy security, the concerns are renewability, supply chain reliability, fuel diversity and obviously economic aspects, such as sustainability, increased farmer income and agricultural development (Utama et al., 2014). Exploring ways to minimize the high cost of biodiesel production is of much interest in today's biodiesel research.

Currently, various vegetable seed-based oils or animal fats are produced in large quantities for use as biodiesel feedstock. The high content of impurities (FFA and moisture) results in the need for an acid-pre-treatment step for crude vegetable oils; otherwise, the oil can certainly not be used as the feedstock of alcoholysis in the presence of alkali as the catalyst. A successful alcoholysis process requires high quality feedstock with the lowest content of impure compounds. In particular, the acid level in the oil should not be higher than $1 \mathrm{mg} \mathrm{KOH} \cdot \mathrm{g}^{-1}$ triglyceride. Kulkarni and Dalai (2006) reported that the alcoholysis of feedstock with a higher FFA level
$(>1.0 \% \mathrm{w} / \mathrm{w})$ caused a saponification reaction which hindered the yield and formation rate of the esters produced. Thus, an acid catalyst was employed to solve this problem. However, the acid-catalyzed alcoholysis reaction resulted in a slow reaction rate and higher temperature requirement due to lower sensitivity to the FFA conversion (Peters et al., 2006). In a similar work, the solid catalyst was applied by other researchers, such as Chan et al. (2010) who used amberlyst 35, Park et al. (2010) who used amberlyst 15, and Peters et al. (2006) who used applied zeolites, and sulphated zirconia and niobium acid as a heterogeneous catalyst for producing vegetable oil-based biodiesel.

Response surface methodology (RSM) is a useful statistical technique for optimizing experimental conditions and investigating the critical processes by reducing the number of experimental trials (Myers and Montgomery, 2002). According to Pinzi et al. (2010), RSM is a powerful tool that has many advantages, such as more information per experiment than unplanned approaches, a reduction in the number and cost of experiments and it makes the calculation of the interactions among experimental variables possible within the range studied, leading to better knowledge of the process. Although the application of RSM for biodiesel production is still used only occasionally (Vicente et al., 2007), some researchers have successfully applied it to optimize the alcoholysis reaction (Abdullah et al., 2009; Jeong et al., 2009; Rashid et al., 2011; Silva et al., 2011).

To obtain a low level of FFA in Oleum papaveris seminis oil as biodiesel feedstock, the focus of this study is the optimization of the esterification process. For this purpose, RSM was employed with effected variables, such as the volume ratio of methanol to oil, percentage of catalyst loading, and reaction time. The kinetic study for the esterification of FFA in Oleum papaveris seminis oil was also performed at three different reaction temperatures $\left(50,55\right.$ and $\left.60^{\circ} \mathrm{C}\right)$ under optimized conditions.

\section{MATERIALS AND METHODS}

\subsection{Materials}

The feedstock used in this study was crude Oleum papaveris seminis oil with an initial FFA content of $(10.63 \%)$. The chemicals employed were methanol $(99.8 \%$ purity), sulphuric acid (95-98\% purity), 
isopropyl alcohol (IPA) (99.7\% purity), phenolphthalein $(1 \%)$, potassium hydroxide $(85 \%$ purity), and amberlite 120 as the solid catalyst with its properties shown in Table 1. The equipment used was as follows: three necked flask (reactor), Graham condenser, magnetic stirrer hot plate, burette, thermometer and other glassware.

\subsection{Experimental procedure}

\subsubsection{Catalyst preparation}

Amberlite 120 is a solid catalyst which requires little preparation. The amberlite was dried in an oven at $100{ }^{\circ} \mathrm{C}$ for 48 hours after being washed with alcohol and sulphuric acid $(98 \%)$, respectively.

\subsubsection{Esterification}

The esterification reaction as shown in Eq. (1) was performed as follows: initially, the crude Oleum papaveris seminis oil was heated in the reactor until the temperature reached about $60^{\circ} \mathrm{C}$. The prepared catalyst (acid-based amberlite 120) was poured into the reactor simultaneously with the methanol at various concentrations as specified previously. Once the reaction was complete the product was transferred into a separating funnel and allowed to settle for two hours. The top layer (methanol-water) was removed. The treated oil was further analyzed for its final value of FFA concentration through acid base titration. The solid catalyst was recovered for reuse.

$$
\mathrm{FFA}+\mathrm{MeOH} \stackrel{\text { Catalyst }}{\longleftrightarrow} \mathrm{ME}+\mathrm{H}_{2} \mathrm{O}
$$

\subsubsection{Titration technique}

The FFA content in the vegetable oil was determined using the acid base titration technique (Eq. 2).

$F F A(\%)=\frac{28.2 \times N \times V}{W}$

TABle 1. Properties of amberlite $120^{\mathrm{a}}$

\begin{tabular}{ll}
\hline Physical form & Amber spherical beads \\
\hline Matrix & $\begin{array}{l}\text { Styrene divinylbenzene } \\
\text { copolymer }\end{array}$ \\
Functional group & Sulfonic acid \\
Ionic from as shipped & $\mathrm{H}^{+}$ \\
Total exchange capacity & $\geq 1.8 \mathrm{eq} \cdot \mathrm{L}^{-1}\left(\mathrm{H}^{+}\right.$form $)$ \\
Moisture holding capacity & $53-58 \%\left(\mathrm{H}^{+}\right.$from $)$ \\
Shipping weight & $800 \mathrm{~g} \cdot \mathrm{L}^{-1}$ \\
Maximum reversible swelling & $\mathrm{Na}^{+} \rightarrow \mathrm{H}^{+} \leq 11 \%$ \\
Maximum operating temperature & $135^{\circ} \mathrm{C}$
\end{tabular}

${ }^{\mathrm{a}}$ Osorio-Viana et al. (2013).
Where: $N, V$ and $W$ denote the normality of the $\mathrm{KOH}$ solution, volume of the $\mathrm{KOH}$ solution, and weight of the oil sample, respectively.

Table 2 shows the initial value of the FFA in crude vegetable oils. A standard solution of $0.1 \mathrm{~N}$ of IPA in a flask was brought to boil on a hot plate. About $0.5 \mathrm{~mL}$ of phenolphthalein were added dropwise with the addition of $0.1 \mathrm{~N} \mathrm{KOH}$ until a faint, but permanent, pink color was obtained. In this study, the sample weight was $2.5 \mathrm{~g}$ with $50 \mathrm{~mL}$ of the neutralized solvent added. The flask was heated to about $40{ }^{\circ} \mathrm{C}$. The sample was then titrated, while shaking gently, with the standard Alkali until the first permanent color change, where the color persisted for at least 30s (Lin et al., 1995).

\subsection{Experimental design}

RSM was used to optimize the esterification of FFA in the Oleum papaveris seminis oil. A fivelevel, three-factor central composite rotatable design requiring a total of 20 experiments was adopted in this work (Jeong et al., 2007; Halim et al., 2009). The ratio of methanol to vegetable oil (A) in the range of $30-50 \% \mathrm{v} / \mathrm{v}$, percent of catalyst loading (B) in the range of $0.5-1.0 \mathrm{wt} \%$, and reaction time $(\mathrm{C})$ in the range of $60-120$ min were selected as parameters. The final percentage of FFA in the treated oil (Y) was selected to be the response variable. Each factor was coded into levels $-\alpha,-1,0,+1$ and $+\alpha$ as shown in Table 3. The experimental design employed together with the results are given in Table 4.

\subsection{Statistical analysis}

The experimental data was obtained by applying the central composite rotatable design procedure. It was analyzed by the response surface regression procedure using the second order polynomial Eq. (3). Second order coefficients were generated via regression. The response was initially fitted to the factors via multiple regressions. The quality of the fit of the model was evaluated using the coefficients of determination $\left(\mathrm{R}^{2}\right)$ and analysis of variance (ANOVA).

$$
Y=b_{0}+\sum_{i=1}^{p} b_{i} x_{i}+\sum_{i=1}^{p} b_{i j} x_{i}^{2}+\sum_{i}^{p} \sum_{j}^{p} b_{i j} x_{i} x_{j}
$$

TABLE 2. Comparison of initial FFA level of different vegetable oils

\begin{tabular}{lc}
\hline Type of oils & Initial value (\%,w/w) \\
\hline Oleum papaveris seminis oil & 10.63 \\
Jatropha curcas oil $^{\mathrm{b}}$ & 25.3 \\
Rubber seed oil $^{\mathrm{c}}$ & 17 \\
Crude palm oil $^{\mathrm{b}}$ & 6.1 \\
\hline
\end{tabular}

${ }^{\mathrm{b}}$ Azhari et al. (2008); ${ }^{\mathrm{c}}$ Ramadhas et al. (2005). 
TABLE 3. Factors and levels for central composite design

\begin{tabular}{lcccccc}
\hline & & \multicolumn{5}{c}{ Coded factor levels } \\
\cline { 3 - 7 } Parameters & Symbol & $\boldsymbol{- \alpha}$ & $\boldsymbol{- 1}$ & $\mathbf{0}$ & $\mathbf{+ 1}$ & $\boldsymbol{+} \alpha$ \\
\hline Ratio of methanol (\% v/v) & $\mathrm{A}$ & 34.05 & 30 & 40 & 50 & 45.95 \\
Percentage of catalyst $(\% \mathrm{w} / \mathrm{w})$ & $\mathrm{B}$ & 0.60 & 0.50 & 0.75 & 1.00 & 0.90 \\
Reaction time $(\mathrm{min})$ & $\mathrm{C}$ & 72.16 & 60 & 90 & 120 & 107.84 \\
\hline
\end{tabular}

TABLE 4. Experimental design for the FFA concentration of Oleum papaveris seminis oil

\begin{tabular}{lcccc}
\hline $\begin{array}{l}\text { Standard } \\
\text { order }\end{array}$ & $\begin{array}{c}\text { Ratio of methanol } \\
(\% \mathbf{~ v / v ) ~} \mathbf{A}\end{array}$ & $\begin{array}{c}\text { Catalyst percentage } \\
(\% \mathbf{w} / \mathbf{w}) \mathbf{B}\end{array}$ & $\begin{array}{c}\text { Reaction time } \\
(\mathbf{m i n}) \mathbf{C}\end{array}$ & $\begin{array}{c}\text { Observed FFA } \\
\text { of oil (\%) }\end{array}$ \\
\hline 1 & $-\alpha$ & $-\alpha$ & $-\alpha$ & 2.59 \\
2 & $+\alpha$ & $-\alpha$ & $-\alpha$ & 1.75 \\
3 & $-\alpha$ & $+\alpha$ & $-\alpha$ & 2.41 \\
4 & $+\alpha$ & $-\alpha$ & $-\alpha$ & 1.29 \\
5 & $-\alpha$ & $-\alpha$ & $+\alpha$ & 1.65 \\
6 & $+\alpha$ & $+\alpha$ & $+\alpha$ & 1.39 \\
7 & $-\alpha$ & $+\alpha$ & $+\alpha$ & 1.31 \\
8 & $+\alpha$ & 0 & $+\alpha$ & 0.32 \\
9 & -1 & 0 & 0 & 2.65 \\
10 & +1 & -1 & 0 & 1.31 \\
11 & 0 & +1 & 0 & 1.85 \\
12 & 0 & 0 & 0 & 1.12 \\
13 & 0 & 0 & -1 & 2.66 \\
14 & 0 & 0 & +1 & 1.21 \\
15 & 0 & 0 & 0 & 1.25 \\
16 & 0 & 0 & 0 & 1.2 \\
17 & 0 & 0 & 0 & 1.24 \\
18 & 0 & 0 & 0 & 1.26 \\
19 & 0 & 0 & 0 & 1.23 \\
20 & 0 & & 0 & 1.22 \\
\hline & $+\alpha$ & & &
\end{tabular}

Values are mean \pm SD.

Where $\mathrm{Y}$ is the response (final concentration of FFA in the treated oil) variable, $i$ and $j$ are the linear and quadratic coefficients, $b$ represents the regression coefficient, $p$ is the number of factors studied and optimized in the present study.

The ANOVA for the response surface quadratic model is shown in Table 5. The coefficients of the response surface model, as provided by Eq. (3) were also evaluated. A p-value showed that all of the linear coefficients were more highly significant than their quadratic and cross-product terms. However, in order to minimize error, all of the coefficients were considered in the design. According to the ANOVA analysis of the factors, a poor fit was obtained. This indicated that the model indeed represented the actual relationships of reaction parameters, which were well within the selected ranges (Table 5). The final estimative response model equation by which the percentage of FFA was estimated was as follows:

$$
\begin{aligned}
\mathrm{Y}= & +27.92-0.69 X_{1}-2.77 X_{2}-0.20 X_{3}+0.006 X_{1}^{2} \\
& +2.49 X_{2}^{2}+0.0006 X_{3}^{2}-0.001 X_{1} X_{2}-0.004 X_{1} X_{3} \\
& +6.51 X_{2} X_{3}
\end{aligned}
$$

Where $\mathrm{X}_{1}, \mathrm{X}_{2}$ and $\mathrm{X}_{3}$ represent the variables of $\mathrm{A}, \mathrm{B}$ and $C$, respectively.

\section{RESULTS AND DISCUSSION}

Since the esterification reaction was required to reduce the free fatty acid (FFA) concentration in the crude vegetable oil, the reaction took place under the reversible mode. The excess of alcohol was needed to increase the conversion of FFA into valuable ester compounds. Figure 1 shows the progress of the esterification reaction at various reaction intervals. The esterification of FFA in Oleum papaveris seminis oil using pure amberlite 120 took a longer time to reduce FFA to less than $1.0 \% \mathrm{w} / \mathrm{w}$ 
Conversion of Oleum papaveris seminis oil into methyl esters via esterification process: Optimization and kinetic study $\bullet 5$

TABLE 5. Analysis of variance (ANOVA) for response surface quadratic model

\begin{tabular}{lcrcrr}
\hline Source & Sum of squares & df & Mean square & F value & p-value \\
\hline Model & 5.65 & 9 & 0.63 & 41.73 & $<0.0001$ \\
A-Ratio of methanol & 1.68 & 1 & 1.68 & 111.37 & $<0.0001$ \\
B-Percentage of catalyst & 0.49 & 1 & 0.49 & 32.84 & 0.0002 \\
C-Reaction time & 1.93 & 1 & 1.93 & 128.01 & $<0.0001$ \\
AB & 0.014 & 1 & 0.014 & 0.90 & 0.3639 \\
AC & 0.24 & 1 & 0.24 & 16.05 & 0.0025 \\
BC & 0.001 & 1 & 0.001 & 0.067 & 0.8006 \\
A $^{2}$ & 0.76 & 1 & 0.76 & 50.71 & $<0.0001$ \\
B $^{2}$ & 0.044 & 1 & 0.044 & 2.91 & 0.1191 \\
C $^{2}$ & 0.66 & 1 & 0.66 & 43.94 & $<0.0001$ \\
Residual & 0.15 & 10 & 0.015 & & \\
Lack of Fit & 0.15 & 5 & 0.030 & 63.48 & 0.0002 \\
Pure Error & 0.0023 & 5 & 0.00047 & & \\
Total & 5.80 & 19 & & & \\
\hline
\end{tabular}

C.V=7.770\%; $\mathrm{R}^{2}=0.974 ;$ adj $\mathrm{R}^{2}=0.951$.

compared to the esterification of FFA with the acid-based amberlite 120 catalyst. Therefore, the latter was applied.

\subsection{Optimization of the processing conditions by response surface methodology}

In this study, the reduction process of the FFA concentration in the oil which corresponded to those parameters (ratio of methanol, percentage of catalyst loading and reaction time) was evaluated by employing RSM. Table 4 shows the results of the experimental work of the central composite rotatable design at each point. Twenty experiments were performed in triplicate. Analysis of the regression was used to fit the emperical model with the generated response variable data (Mason et al., 1989). The response variable (Table 4) was correlated with the three independent parameters using the polynomial equation (Eq. 3).

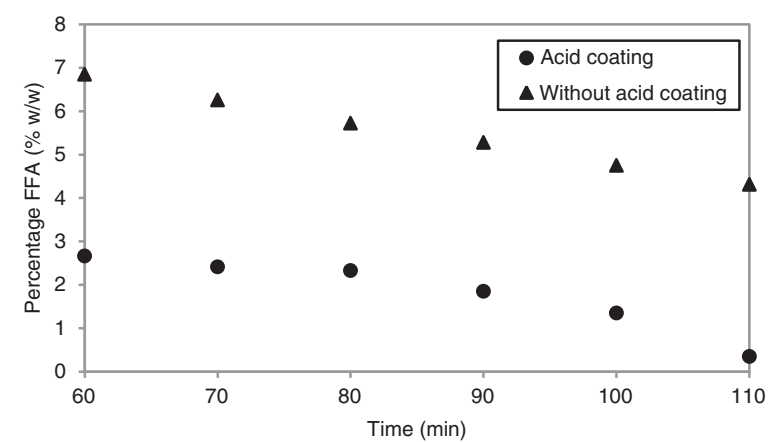

FiguRE 1. Progress of FFA esterification over various reaction times.
The observed and predicted values of the FFA level in the treated oil at the designated points of different esterification reaction conditions are shown in Figure 2. The lowest percentage of the FFA concentration $(0.60 \%)$ was obtained at the $44.70 \% \mathrm{v} / \mathrm{v}$ ratio of methanol, $0.87 \%$ wt catalyst loading, and 102.40 min reaction time.

Design-Expert 8 software (Stat-Ease, Inc. Minneapolis, USA) was used to determine and evaluate the coefficient of the full regression model equation and its statistical significance. Models were analyzed and validated by analysis of variance (ANOVA). The model appears to be adequate for the observed data at a $95 \%$ confidence level and $\mathrm{p}$ values of $<0.05$. As the obtained data was analyzed using ANOVA (Table 5), satisfactory representation of the real relationship among the selected factors as shown in the $95 \%$ confidence level, the model

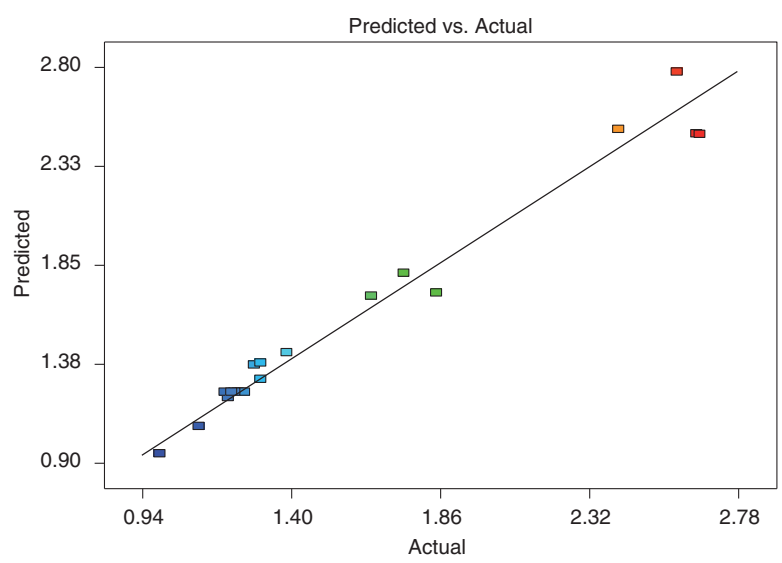

FIGURE 2. Plot of actual vs. predicted values of FFA. 
TABLE 6. Regression coefficients and significance of response surface quadratic model

\begin{tabular}{lcccccc}
\hline Factor & Coefficient estimate & df & Standard error & $\mathbf{9 5 \%}$ CI low & $\mathbf{9 5 \%}$ CI high & VIF \\
\hline Intercept & 1.24 & 1 & 0.050 & 1.13 & 1.35 & \\
A & -0.35 & 1 & 0.033 & -0.42 & -0.28 & 1.00 \\
B & -0.19 & 1 & 0.033 & -0.26 & -0.12 & 1.00 \\
C & -0.38 & 1 & 0.033 & -0.45 & -0.30 & 1.00 \\
AB & -0.041 & 1 & 0.043 & -0.14 & -0.05 & 1.00 \\
AC & 0.17 & 1 & 0.043 & -0.07 & 0.27 & 1.00 \\
BC & -0.01 & 1 & 0.043 & -0.11 & 0.08 & 1.00 \\
$A^{2}$ & 0.23 & 1 & 0.032 & 0.16 & 0.30 & 1.02 \\
B $^{2}$ & 0.06 & 1 & 0.032 & -0.02 & 0.13 & 1.02 \\
C $^{2}$ & 0.21 & 1 & 0.032 & 0.14 & 0.29 & 1.02 \\
\hline
\end{tabular}

was found to be significant as the computed $F$ value $\left(\mathrm{F}_{\text {model }}=41.73\right)$ with a very low probability value ( $\mathrm{p}$-value $<0.0001$ ) indicated the high significance of the fitted model which also shows the reliability of the regression model for predicting the percentage of FFA in the treated feedstock oil (Lee et al., 2005). As previously reported by Rashid et al. (2011), the model coefficient and probability values support the fact that the model was suitable for Table 6 . The normal probability plot of residuals is indicated in Figure 3. It also reveals that the distribution of the data along the resultant curve showed the normality of the data due to an almost linear plot.

\subsection{Esterification of FFA in Oleum papaveris seminis oil}

To investigate the characteristic of the esterification process in the presence of acid-based amberlite 120 , a reuse test of the catalyst was carried out. The catalyst was reused for five cycles after being separated from the reaction products (Figure 4). The affecting variables, such as reaction time, ratio of

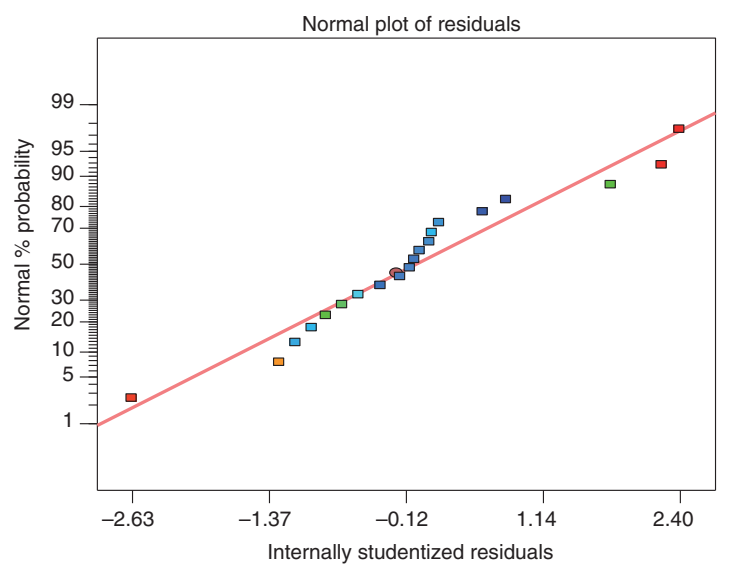

FIGURE 3. Normal probability plot of residuals. methanol, and percentage of catalyst loading, were applied in this process. In a previous study, Ghadge and Raheman (2005) reported that the reduction of the FFA concentration in vegetable oils was influenced by the amount of catalyst loading. The present study indicates that the symptom of the FFA level reduction was affected significantly by increasing the reactant volume and catalyst percentage as shown in Figure 5a-c.

The effect of the increase in the methanol concentration on the reduction of FFA levels in the crude Oleum papaveris seminis oil showed that the ratio of methanol was an important variable in the esterification process. Figure $5 \mathrm{a}-\mathrm{c}$ show that the reduction in FFA levels was proportional to the intercalation of the methanol. At $38 \% \mathrm{v} / \mathrm{v}$ of methanol, the FFA levels dropped to $2.01 \%$. As the ratio of methanol increased to more than $40 \% \mathrm{v} / \mathrm{v}$, the FFA levels in the oil decreased significantly to $<1.0 \%$. However, the optimum ratio of methanol applied in this study was $44.70 \% \mathrm{v} / \mathrm{v}$. A similar work reported that the optimum condition of the esterification of oleic acid with amberlyst 15 and amberlyst

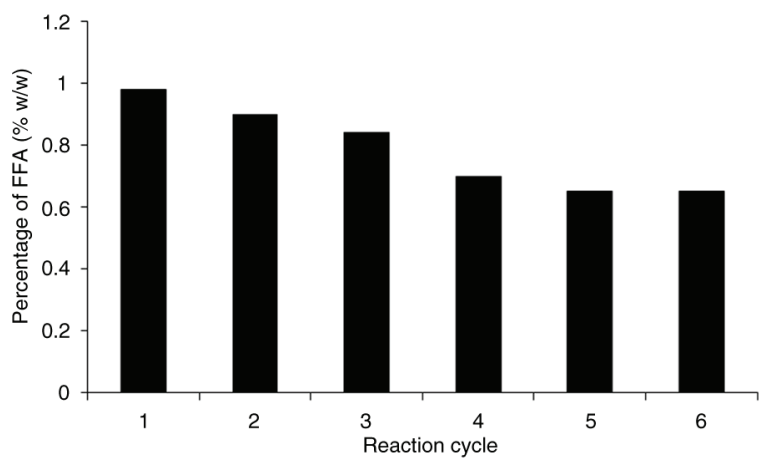

FIGURE 4. Reusability of the amberlite 120 catalyst. The experiment was done under optimum the condition: catalyst concentration $(0.87 \% \mathrm{w} / \mathrm{w})$; percentage of methanol to oil ratio $(44.70 \% \mathrm{v} / \mathrm{v})$ and of reaction time $(102.5 \mathrm{~min})$. 
(a)
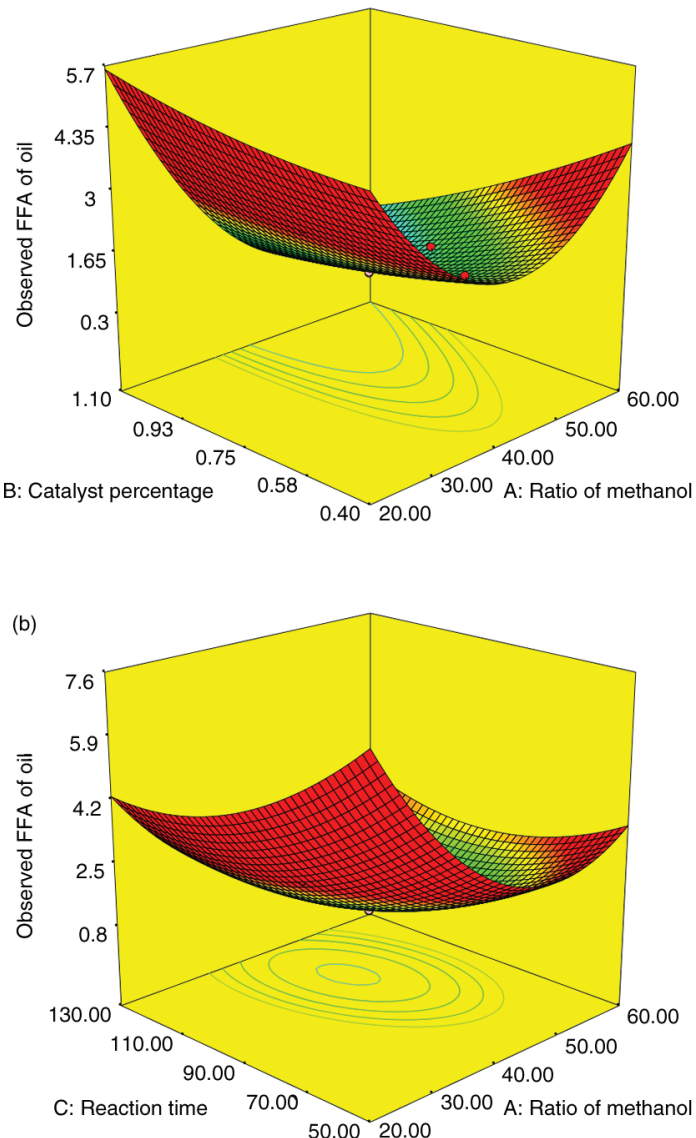

(c)

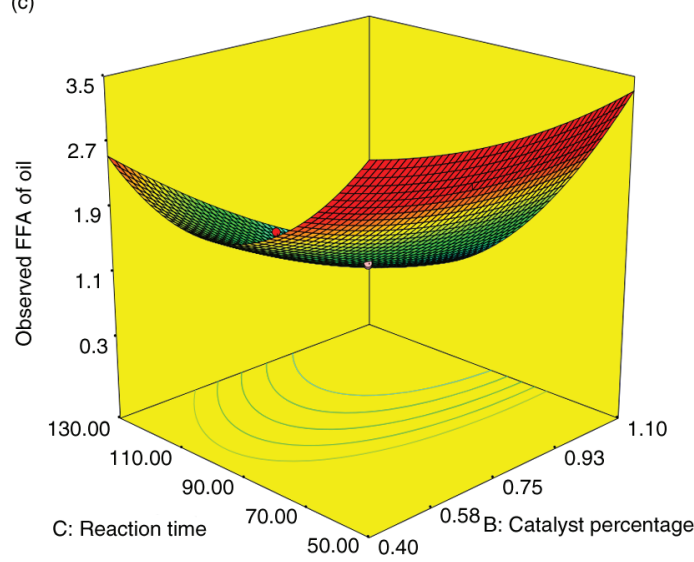

FIGURE 5. Surface plots of FFA reduction of Oleum papaveris seminis oil.

BD20 required 20\% wt of the catalyst and a 6:1 molar ratio of methanol (Park et al., 2010).

The reduction in the FFA level in the oil clearly depended on the time span of the reaction. Even though other parameters played important roles in alleviating the FFA percentage, the esterification reaction time seemed to have a considerable effect on the final FFA level as shown in Figure 5b and $5 \mathrm{c}$. From those Figures, it was observed that the FFA level in the oil was alleviated with an increasing reaction time. The FFA level reduced sharply to less than $1.0 \%$ at 102.40 min of reaction time. Tesser et al. (2010) reported that the optimum reaction time for reducing the FFA levels in a soybean oil-oleic acid mixture was $150 \mathrm{~min}$ in the presence of $1.0 \%$ catalyst (acid exchange resin).

From Table 5, it can be seen that the high $(\mathrm{F})$ value and the low value of its corresponding $(p)$ value showed that the linear term of the methanol ratio $(\mathrm{A})$, percentage of catalyst (B), and reaction time (C) significantly affected the reduction of the FFA levels in the crude Oleum papaveris seminis oil. The quadratic term of the reaction time $\mathrm{C}(\mathrm{F}$ value $=128.01)$ was more significant than the methanol ratio $\mathrm{A}(\mathrm{F}$ value $=111.37)$ and the catalyst percentage $\mathrm{B}(\mathrm{F}$ value $=32.84)$. The quadratic effect of the interaction variables between the methanol ratio and reaction time was predominant $(F$ value $=16.05$ and $p$-value $=0.0025)$ as compared to the methanol ratio with the percentage of catalyst $(F$ value $=0.90$ and $p$-value $=0.3639)$ and the percentage of the catalyst with the reaction time ( $F$ value $=0.067$ and $p$-value $=0.0025)$.

\subsection{Kinetics model}

The kinetics study on the FFA reduction in Oleum papaveris seminis oil was conducted at three reaction temperatures $\left(50,55\right.$ and $\left.60^{\circ} \mathrm{C}\right)$ and two optimized parameters (ratio of methanol $(44.70 \% \mathrm{v} / \mathrm{v})$ and percentage of catalyst loading $(0.87 \%(\mathrm{w} / \mathrm{w}))$. In this study, the kinetics samples were taken at identical reaction times from $10 \mathrm{~min}$ to $110 \mathrm{~min}$ in order to observe the rate of the FFA conversion into valuable alkyl esters. Thus, a simplification of the esterification reaction mechanism was carried out to obtain a simple mathematical equation. Therefore, this esterification reaction was assumed to be taking place in an irreversible mode. The rate of the FFA reduction in the oil of the feedstock was derived mathematically based on Eq. (1) to generate Eqs. (5) to (7).

$$
\text { rate }=-\frac{d\left(C_{F F A}\right)}{d t}=k\left(C_{F F A}\right)
$$

Eq. (5) was integrated to get Eq. (6)

$k=\frac{1}{t} \ln \frac{\left(C_{F F A_{0}}\right)}{\left(C_{F F A}\right)}$

Using log to the base 10, Eq. (6) becomes:

$k=\frac{2.303}{t} \log _{10}\left(\frac{C_{F F A_{0}}}{C_{F F A}}\right)$ 
Where: $k$ is the overall rate constant for FFA, $t$ is the reaction time and $C_{F F A}$ is the FFA concentration of the oil at the initial time $(\mathrm{t}=0 \mathrm{~min})$. For the alcoholysis of FFA, a plot of the reaction time $(t)$ against $\log \frac{\left(C_{F F A_{0}}\right)}{\left(C_{F F A}\right)}$ will generate a straight line if the value of the first order model is obtained. Figure 6 shows the data plots at temperatures 50, 55 , and $60{ }^{\circ} \mathrm{C}(323,328$ and $333 \mathrm{~K})$. Thus, the slope of $2.303 / \mathrm{k}$ was applied in calculating the rate constant of reaction $(k)$. The values of $k$ and their corresponding correlation coefficients are shown in Table 7. The results indicate that the endothermic behavior of the esterification process was considerably influenced by the amount of heat applied. It was proved that increasing the reaction temperature raised the reaction rate constant $(k)$ as shown in Table 7. In a similar study, Su (2013) reported that $k$ values increased with the reaction temperature. However, when the data was plotted in the second order model, the graph did not produce a straight line and it revealed that the esterification process did not match the reaction order. From Figure 5, it can be observed that a reasonable distribution of data plotted for the entire reaction showed identical temperatures, reflecting a fit of the experimental data as indicated by the high coefficient of determination values as shown in Table 7. Then, the curve slope-based calculation of the reaction rate constants $(k)$ was determined with a very simple mathematical method. The whole of the $k$ values was tabulated afterwards in Table 7 .

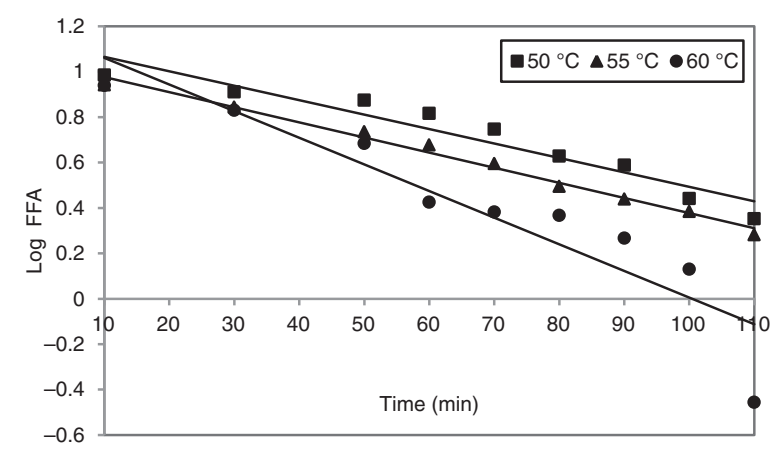

FiguRE 6. First order kinetics model for esterification of FFA in Oleum papaveris seminis oil at various temperatures.

TABLE 7. Esterification reaction rate constant of FFA in Oleum papaveris seminis oil

\begin{tabular}{lcc}
\hline Temperature $\left({ }^{\circ} \mathbf{C}\right)$ & $\boldsymbol{k}\left(\mathbf{m i n}^{-\mathbf{1}}\right)$ & $\mathbf{R}^{\mathbf{2}}$ \\
\hline 50 & 0.013 & 0.92 \\
55 & 0.015 & 0.98 \\
60 & 0.027 & 0.90 \\
\hline
\end{tabular}

Theoretically, it revealed that the reaction rate constant for any reaction depends on two factors, such as the frequency of collisions among the reactant molecules and the values of the activation energy. The dependency of the rate constant, $k$, on the temperature follows the Arrhenius equation (8):

$$
k=A \exp (-E / R T)
$$

Therefore, Eq. (8) was substituted into the logarithmic form as given by Eq. (9).

$$
\log _{10} k=(-E / 2.303 R T)+\log _{10} A
$$

Where $\mathrm{T}$ is the reaction temperature which was expressed in ${ }^{\circ} \mathrm{K}$ and $R$ denotes the universal gas constant. The activation energy $(E)$ was estimated from the slope of a plot of $\log _{10} k$ versus $1 / \mathrm{T}$. The frequency factor, $A$, was determined from the y-intercept. The data shown in Table 7 at various reaction temperatures were used to determine the Arrhenius activation energy. An Arrhenius plot for the esterification of FFA in Oleum papaveris seminis oil at $50-60{ }^{\circ} \mathrm{C}\left(323-333^{\circ} \mathrm{K}\right)$ showed a straight line, obtaining the activation energy for the direct reaction as seen in Figure 7. A high reaction temperature was required for increasing the dissolution rate and solubility of FFA in methanol. On the other hand, at lower temperatures, the dissolution rate was slow and the solubility of FFA was also limited. In this matter, generally, the activation energies were used for describing a further reaction scenario. Based on the chemical kinetics theory, high activation energy was needed by a chemical reaction for breaking down the tetrahedral intermediate compounds to turn into the main product and by-product after those form the initial complex and transition states which consumed low activation energy. Similar work reported that the necessity of the activation energy for the esterification of FFA in sunflower oil was about $50.7 \mathrm{KJmol}^{-1}$ (Berrios et al., 2007). However, in this study, the activation energy for the esterification of FFA in Oleum papaveris seminis oil was $60.9 \mathrm{KJmol}^{-1}$.

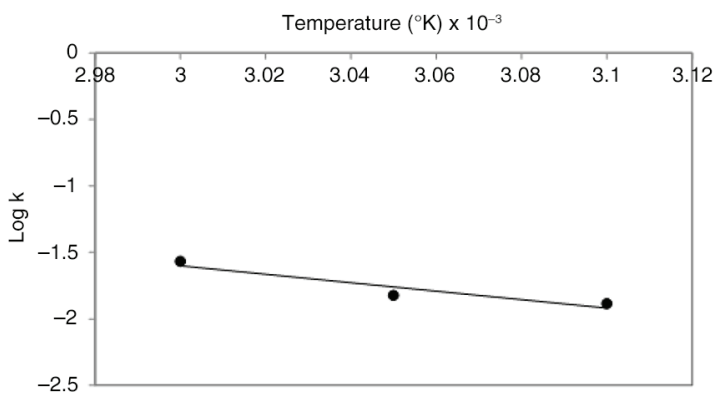

Figure 7. Arrhenius plot showing the temperature dependency of reaction rate constants. 


\section{CONCLUSIONS}

Optimization of the esterification process to reduce the FFA concentration in Oleum papaveris seminis oil in the presence of amberlite 120 as a solid catalyst was carried out. The various effecting parameters such as the ratio of methanol $(\% \mathrm{v} / \mathrm{v})$, percentage of catalyst loading $(\% \mathrm{wt})$, and reaction time $(\mathrm{min})$ were optimized. A design expert on response surface methodology (RSM) with the central composite rotatable design was employed to determine and evaluate the experimental work model. The optimized conditions were $102.4 \mathrm{~min}$ of reaction time, $44.70 \% \mathrm{v} / \mathrm{v}$ of methanol ratio, and $0.87 \%$ wt of catalyst loading. Then, the kinetic study on the esterification of the FFA in Oleum papaveris seminis oil with methanol was investigated at three reaction temperatures $(50,55$ and $60{ }^{\circ} \mathrm{C}$ ). The results showed that the reaction followed a first order kinetics model with reaction rate constants $(k)$ and activation energy in the range of 0.013 to $0.027 \mathrm{~min}^{-1}$ and $60.9 \mathrm{KJmol}^{-1}$, respectively.

\section{ACKNOWLEDGEMENT}

The authors would like to extend their sincere appreciation to the Deanship of Scientific Research at King Saud University for its funding of this research through the Research Group Project number RGP-VPP-048.

\section{REFERENCES}

Abdullah AZ, Razali N, Lee KT. 2009. Optimization of mesoporous K/SBA-15 catalyzed transesterification of palm oil using response surface methodology. Fuel Proc. Technol. 90, 958-964. http://dx.doi.org/10.1016/j.fuproc.2009.03.023.

Aransiola EF, Ojumu TV, Oyekola OO, Madzimbamuto TF, IkhuOmoregbe DIO. 2014. A review of current technology for biodiesel production: State of the art. Biomass Bioenerg. 61, 276-297. http://dx.doi.org/10.1016/j.biombioe.2013.11.014.

Azhari, Faiz M, Yunus R, Ghazi TIM, Yaw TCS. 2008. Reduction of free fatty acids in crude Jatropha curcas oil via an esterification process. Int. J. Eng. Technol. 5, 92-98.

Berrios M, Siles J, Martín MA, Martín A. 2007. A kinetic study of the esterification of free fatty acids (FFA) in sunflower oil. Fuel, 86, 2383-2388. http://dx.doi.org/10.1016/j. fuel.2007.02.002

Chan KW, Tsai YT, Lin HM, Lee MJ. 2010. Esterification of adipic acid with methanol over Amberlyst 35. J. Taiwan Inst. Chem. Eng. 41, 414 420. http://dx.doi.org/10.1016/j. jtice.2009.12.001

Ghadge SV, Raheman H. 2005. Biodiesel production from mahua (Madhuca indica) oil having high free fatty acids. Biomass Bioenerg. 28, 601-605. http://dx.doi.org/10.1016/j. biombioe.2004.11.009

Halim SFA, Kamaruddin AH, Fernando WJN. 2009. Continuous biosynthesis of biodiesel from waste cooking palm oil in a packed bed reactor: Optimization using response surface methodology (RSM) and mass transfer studies. Bioresource Technol. 100, 710-716. http://dx.doi.org/10.1016/j.biortech. 2008.07.031.

Jeong GT, Yang HS, Park DH. 2009. Optimization of transesterification of animal fat ester using response surface methodology. Bioresource Technol. 100, 25-30. http://dx.doi.org/ $10.1016 /$ j biortech 2008.05 .011 .

Jeong GT, Kim DH, Park DH. 2007. Response surface methodological approach for optimization of free fatty acid removal in feedstock. In: Mielenz J, Klasson KT, Adney W,
McMillan J (Eds.) Applied Biochemistry and Biotecnology, Humana Press, pp. 583-593.

Kulkarni MG, Dalai AK. 2006. Waste cooking oil an economical source for biodiesel: A review. Ind. Eng. Chem. Res. 45, 2901-2913. http://dx.doi.org/10.1021/ie0510526.

Lin S, Sue TT, Ai TY. 1995. PORIM test methods, in, Palm Oil Research Institute of Malaysia, Kuala Lumpur.

Lee KT, Matlina Mohtar A, Zainudin NF, Bhatia S, Mohamed AR. 2005. Optimum conditions for preparation of flue gas desulfurization absorbent from rice husk ash. Fuel, 84, 143-151. http://dx.doi.org/10.1016/j.fuel.2004.08.018.

Ma F, Hanna MA. 1999. Biodiesel production: a review. Bioresource Technol. 70, 1-15. http://dx.doi.org/10.1016/ S0960-8524(99)00025-5.

Mason RL, Gunst RF, Hess JL. 1989. Statistics design and analysis of experiments: with applications to engineering and science, Wiley, New York.

Mohr SH, Wang J, Ellem G, Ward J, Giurco D. 2015. Projection of world fossil fuels by country. Fuel, 141, 120-135. http:// dx.doi.org/10.1016/j.fuel.2014.10.030

Myers RH, Montgomery DC. 2002. Response surface methodology: Process and process optimization using designed experiments, Wiley, New York.

Osorio-Viana W, Duque-Bernal M, Fontalvo J, Dobrosz-Gómez I, Gómez García MÁ. 2013. Kinetic study on the catalytic esterification of acetic acid with isoamyl alcohol over Amberlite IR-120. Chem. Eng. Sci. 101, 755-763. http:// dx.doi.org/10.1016/j.ces.2013.07.009.

Park JY, Kim DK, Lee JS. 2010. Esterification of free fatty acids using water-tolerable Amberlyst as a heterogeneous catalyst. Bioresource Technol. 101, S62-S65. http://dx.doi. org/10.1016/j.biortech.2009.03.035.

Peters TA, Benes NE, Holmen A, Keurentjes JTF. 2006. Comparison of commercial solid acid catalysts for the esterification of acetic acid with butanol. Appl. Catal. A. Gen. 297, 182-188. http://dx.doi.org/10.1016/j.apcata.2005.09.006.

Pinzi S, Lopez-Gimenez FJ, Ruiz JJ, Dorado MP. 2010. Response surface modeling to predict biodiesel yield in a multi-feed stock biodiesel production plant. Bioresource Technol. 101, 9587-9593. http://dx.doi.org/10.1016/j.biortech.2010.07.076.

Radjiyev A, Qiu H, Xiong S, Nam K. 2015. Ergonomics and sustainable development in the past two decades (1992-2011): Research trends and how ergonomics can contribute to sustainable development. Appl. Ergono. 46, 67-75. http://dx.doi. org/10.1016/j.apergo.2014.07.006

Ramadhas AS, Jayaraj S, Muraleedharan, C. 2005. Biodiesel production from high FFA rubber seed oil. Fuel, 84, 335-340. http://dx.doi.org/10.1016/j.fuel.2004.09.016.

Rashid U, Anwar F, Ashraf M, Saleem M, Yusup S. 2011. Application of response surface methodology for optimizing transesterification of Moringa oleifera oil: Biodiesel production. Energ. Conver. Manag. 52, 3034-3042. http:// dx.doi.org/10.1016/j.enconman.2011.04.018.

Silva GF, Camargo FL, Ferreira ALO. 2011. Application of response surface methodology for optimization of biodiesel production by transesterification of soybean oil with ethanol. Fuel Proc. Technol. 92, 407-413. http://dx.doi.org/ 10.1016/j.fuproc.2010.10.002.

$\mathrm{Su}$ CH. 2013. Kinetic study of free fatty acid esterification reaction catalyzed by recoverable and reusable hydrochloric acid. Bioresource Technol. 130, 522-528. http://dx.doi.org/ 10.1016/j.biortech.2012.12.090.

Tesser R, Di Serio M, Casale L, Sannino L, Ledda M, Santacesaria E. 2010. Acid exchange resins deactivation in the esterification of free fatty acids. Chem. Eng. J. 161, 212-222. http:// dx.doi.org/10.1016/j.cej.2010.04.026.

Utama NA, Fathoni AM, Kristianto MA, McLellan BC. 2014. The end of fossil fuel era: Supply-demand measures through energy efficiency. Proc. Environ. Sci. 20, 40-45. http://dx.doi. org/10.1016/j.proenv.2014.03.007.

Vicente G, Martínez M. Aracil J. 2007. Optimisation of integrated biodiesel production. Part I. A study of the biodiesel purity and yield. Bioresource Technol. 98, 1724-1733. http://dx.doi.org/10.1016/j.biortech.2006.07.024.

Wu J, Gao Y, Zhang W, Tan Y, Tang A, Men Y, Tang B. 2014. Esterification of cooking oil for biodiesel production using composites $\mathrm{Cs}_{2.5} \mathrm{H}_{0.5} \mathrm{PW}_{12} \mathrm{O}_{40}$ /ionic liquids catalysts. Appl. Petrochem. Res. 4, 305-312. http://dx.doi.org/10.1007/ s13203-014-0066-x. 